\title{
Spicular analysis of surficial sediments as a supplementary tool for studies of modern sponge communities
}

\author{
Magdalena Łukowiak
}

\begin{abstract}
The method of spicular analysis that examines surficial sediments has been used to study the sponge spicule assemblage in the lagoon reef of Bocas del Toro, Panama. The method allowed to recognize some highly diagnostic spicule morphotypes that may belong to four sponge species as yet unnoticed in this area. The presence of these sponges must have been overlooked while studying faunistic compositions within an ecosystem due to their cryptic and/or excavating nature. Despite some limitations, the method of spicular analysis may be used as a supplementary tool for the studies of modern shallow-water sponge communities.
\end{abstract}

Keywords: Cryptic sponges, Excavating sponges, Triptolemma endolithicum, Alectona wallichii, Samus anonymus, Cliona mucronata

\section{Background}

Sponges are sessile filter feeders that inhabit marine and fresh-water ecosystems all over the world. They are the main component of marine fauna and, next to corals, are one of the most important organisms inhabiting reefs and shallow-water habitats [16]. Sponges can also be the key components of deep-sea environments (e.g., [27, 54]). In the past, they usually received considerably less attention than other marine organisms. However, there has been an increase of interest in sponges over the last decades $[16,28,66]$.

In spite of the fact that marine sponge fauna is now under intensive studies, in some, even well-studied regions, sponges are still poorly known. The most investigated areas with the best known sponge fauna include Mediterranean, Caribbean, and Australia (e.g., [63]). Still, there are new sponge species described from these sponge-rich regions every year (e.g., $[18,51,64,67,68]$ ), and it is presumed that there is still about twice as many species unknown to scientists [66]; particularly small, cryptic, or excavating species are difficult to observe and

*Correspondence: mlukowiak@twarda.pan.pl

Institute of Paleobiology PAN, Twarda 51/55, 00-818 Warsaw, Poland sometimes are overlooked. Thus, sponge inventory lists are incomplete.

The main characters used in sponge identification for ecological/general field studies include: shape, color, and consistency of a specimen (e.g., see [13]). However, it is especially the type and the arrangement of the internal mineral skeleton consisting of spicules that is crucial for sponge taxonomical assignment (e.g., see [29]).

Hexactinosan hexactinellid sponges may have a fused skeleton derived from secondary deposition of silica over spicules originally secreted loosely, while lithistid demosponges may have articulated spicules. Spicules can also appear free in the sponge body (as in the case of some hexactinellids) [35]. In the class Demospongiae, the spicules are frequently joined by spongin. The diversity of spicule morphotypes in demosponges is great as there are several hundred spicule morphotypes distinguished in this group (e.g., [8]).

Moreover, the spicule combination within a sponge skeleton is an important feature for sponge classification. Some sponges possess spicules of only one type, while others are characterized by a set of several morphotypes. The spicule set of each species is genetically controlled. However, under unfavorable conditions such as low silica levels in the seawater, not all morphotypes proper to the 
sponge are produced [39]. Some morphologies are widespread across the classification, while others are much more restricted in occurrence and thus play an important diagnostic role.

\section{The spicular analysis method}

Sponge spicules may be incorporated in the sediment in several ways. For example, they may become part of the sediment after the sponge's death when the body disintegrates and the mineral spicules remain. They are then the only proof of the sponge's former existence. Heavy storms usually cause detachment of sponge body parts, which may disintegrate and contribute isolated spicules to the sediment. They can also be torn off by various sponge-feeding animals [72]. Thus, under favorable preservation conditions, spicules may give information about the sponges that live or had lived recently in the studied area (see, for example, [6]).

The method of spicular analysis investigates isolated sponge spicules from the sediment and identifies them by comparing them with the spicules of living sponges. This method is usually used to reconstruct fossil and subfossil sponge communities. It has become popular in the middle of the twentieth century when it has been applied to reconstruct ancient marine sponge communities (e.g., $[32,33])$. Later, it was used for reconstructing both fossil marine (e.g., [5-7, 30, 31, 37, 46]) and fresh-water sponge associations from all over the world [24-26, 44, $45,69,70]$. However, the spicular analysis technique can also be used to supplement studies of modern sponge communities by indicating the presence of some difficultto-track sponge species.

\section{Methods}

The surficial sediment samples were collected in June 2011 and July 2014 by SCUBA surveys in patch reef environments of the Bocas del Toro archipelago, on the northwestern coast of Panama (Fig. 1). The studied area lies within the Almirante Bay and represents a diverse, well-developed patch reef with a well-studied coralsponge community (e.g., [13, 15, 17, 19, 21, 22]). Two surface sediment samples, down to a depth of $\sim 1 \mathrm{~cm}$, were recovered in plain patches of shallow-water $(\sim 8 \mathrm{~m})$ reef sand $\left(9^{\circ} 21^{\prime} 38.6^{\prime \prime} \mathrm{N} / 82^{\circ} 16^{\prime} 40.9^{\prime \prime} \mathrm{W}\right.$ and $9^{\circ} 21^{\prime} 42.98^{\prime \prime} \mathrm{N} / 82^{\circ} 16$ '47.6'(W).

The obtained sediments were processed in the Bocas del Toro Research Station laboratory. The samples were subsequently dried and then treated with hydrogen peroxide (30\%) in order to remove small particles of organic matter. Additionally, a small amount of sediment was treated by acetic acid (60\%) to remove carbonates and thus concentrating siliceous spicules in order to make the rare spicule morphotypes easier to find. The sponge spicules were then transported to the Institute of Paleobiology, Polish Academy of Sciences, Poland, for the further analysis. The spicules were then handpicked from the residue under a binocular microscope NIKON SMZ1270. All representatives of morphological spicule types found in the sediment were mounted on SEM stubs and identified using the SEM. The photographed spicule



Fig. 1 Map of the sampling area after Łukowiak et al. [36] (modified) 
morphotypes were compared to spicules that belong to sponges listed from the Bocas del Toro region (Table 1). The sponge list was compiled from published data, e.g., $[10,13,15,17,19,21,22]$ and the STRI webpage database. Next, the studied spicules were compared with the spicules of sponges noted from the wider Caribbean area [e.g., [1, 23, 61, 62, 64, 73, 74]; World Porifera Database (WPD)]. For details of the terminology used in this paper, see the Thesaurus of Sponge Morphology [8] and Systema Porifera [29].

The spicule assemblages are deposited in the Institute of Paleobiology, Polish Academy of Sciences, Warszawa, Poland, under ZPAL Pf.24 and ZPAL Pf.25.

\section{Results}

Among numerous spicules that are present in the sediment, some can be assigned to sponges already known from the investigated area (for the full list of sponges of Bocas del Toro, see Table 1), and some are noted from the study area for the first time. The spicule morphotypes belonging to species as yet unnoted from Bocas del Toro are described, and their taxonomical position is discussed below.

\section{Amphitriaenes of Samus anonymus Gray, [20]}

The spicules found in the surface sediments of the Bocas del Toro lagoon are short-shafted amphiprotriaenes with clads directed forward, away from the rhabd. The cladi are always divided three times. The amphitriaenes vary from slender with well-developed rhabd and thin cladi (Fig. 2c, e) to stout ones with short rhabd and cladi (Fig. 2d, f). The rhabds vary from 30 to $50 \mu \mathrm{m}$ in length and $20-75 \mu \mathrm{m}$ in thickness. The total length of the spicule may exceed $400 \mu \mathrm{m}$. They are identical with spicules of Samus anonymus.

\section{Remarks}

Samus anonymus is characterized by small amphitriaenes (Fig. 2a, b) and sigmaspire microscleres. The megascleres may be short-shafted amphiprotriaenes with clads directed forward, away from the rhabd, or amphiplagiotriaenes with the forward-directed clads forming with the rhabd an angle of about $45^{\circ}$ [8]. However, the cladi do not always divide three times and some are only divided dichotomously [65]. The rhabds vary from 20 to $80 \mu \mathrm{m}$ in length and by up to $38 \mu \mathrm{m}$ in thickness. The cladome may be up to $160 \mu \mathrm{m}$, and the total length of an amphitriaene including cladi may exceed $150 \mu \mathrm{m}$ [65]. Samus anonymus occupies cavities of the porous concretion and the chambers previously excavated by boring sponges [6]. This tetractinellid was first considered to belong to Hadromerida [20, 56, 71] and Homosclerophorida [14]; its lithistid affinity was also considered [65]. Currently, it is regarded as the only species within family Samidae (suborder Spirophorina; [42]).

This cosmopolitan species inhabits shallow-water habitats of the Pacific and Atlantic Oceans, Brazil, Indian Ocean, Mediterranean, and Australia. It was also reported from Cuba, Colombia, Gulf of Mexico, and the Caribbean Sea ([51], WPD). So far, however, it was not reported in Bocas del Toro.

\section{Mucronate tylostyles of Cliona mucronata Sollas, [52]}

The spicules found in the surface sediments of Bocas del Toro are short, stout tylostyles with spherical heads and with a well-defined mucronate tip (Fig. 3c-f). The length of the spicules varies from $120-150 \mu \mathrm{m} \times 18-22 \mu \mathrm{m}$. The head is $16-19 \mu \mathrm{m} \times 17-21 \mu \mathrm{m}$. Even though the straight, thin tylostyles of Cliona mucronata are similar to tylostyles of some other clionaid spicules (e.g., Cliona ampliclavata, C. aprica, C. tenuis; for more details, see [74], the mucronate tylostyles do not resemble spicules of any other clionaid including species inhabiting this and adjacent areas (e.g., Cliona aprica, C. caribbea, C. delitrix, C. langae; compare also with [43, 74]).

\section{Remarks}

Cliona mucronata is characterized by 2 kinds of tylostyles: straight, short, stout tylostyles with spherical heads (sometimes trilobed) and mucronate tips (Fig. 3a, b); and straight, thin tylostyles with oval or spherical heads and hastate tips. In addition to macroscleres, $C$. mucronata also possess spiraster microscleres that are sometimes transformed into branched amphiasters [9]. The mucronate tylostyles are of about $64-89 \mu \mathrm{m} \times 11.5-$ $12.5 \mu \mathrm{m}[9,59]$ and with a head of $6.6-14 \times 8-11.5 \mu \mathrm{m}$ [59].

These clionaids (order Clionaida) are excavating, mostly cryptic sponges. They occupy small holes and chambers excavated in a solid calcareous base $[49,52]$. They often live, overgrow, and bore in other sponges or corals (see [9]).

Cliona mucronata inhabits the Indian Ocean (including Indo-Pacific Ocean), Indonesia, Madagascar, and Australia (WPD; $[9,58]$ ). This species is not listed for Bocas del Toro in any available source. The nearest locality to Bocas del Toro from which it was noted is the Mexican Tropical Pacific [2] but with some doubts (for more details see WPD).

\section{Tuberculate diactines of Alectona wallichii [11]}

The spicules found in the sediment of Bocas del Toro lagoon are very rare and are always broken. However, despite the fragmentation, the mushroom-shaped knobs that cover (most likely) the diactinal spicule forming the longitudinal rows of tubercles are well defined (Fig. 4c). 
Table 1 Sponge list noted from Bocas del Toro, Panama

\begin{tabular}{|c|c|c|}
\hline Order & Family & Species \\
\hline \multirow[t]{9}{*}{ Verongiida } & Aplysinidae & Aiolocroia crassa (Hyatt, 1875) \\
\hline & & Aplysina lacunosa (Lamarck, 1814) \\
\hline & & Aplysina archeri (Higgin, 1875) \\
\hline & & Aplysina fulva (Pallas, 1776) \\
\hline & & Aplysina cauliformis (Carter, 1882) \\
\hline & & Aplysina insulares Duchassaing \& Michelotti, 1864 \\
\hline & & Aplysina fistularis (Pallas, 1766) \\
\hline & & Verongula rigida Esper, 1794 \\
\hline & & Verongula reiswigi Alcolado, 1984 \\
\hline \multirow[t]{12}{*}{ Dictyoceratida } & Irciniidae & Ircinia sp. \\
\hline & & Ircinia strobilina (Lamarck, 1816) \\
\hline & & Ircinia felix (Duchassaing \& Michelotti, 1864) \\
\hline & & Ircinia campana (Lamarck, 1814) \\
\hline & & Dysidea etheria de Laubenfels, 1936 \\
\hline & Spongiidae & Spongia sp. \\
\hline & & Spongia (Spongia) pertusa Hyatt, 1877 \\
\hline & & Spongia (Spongia) tubulifera Lamarck, 1814 \\
\hline & & Hyattella cavernosa (Pallas, 1766) \\
\hline & & Hyattella intestinalis (Lamarck, 1814) \\
\hline & Thorectidae & Hyrtios sp. \\
\hline & & Hyrtios proteus Duchassaing \& Michelotti, 1864 \\
\hline \multirow[t]{28}{*}{ Haplosclerida } & Petrosiidae & Xestospongia sp. \\
\hline & & Xestospongia muta (Schmidt, 1870) \\
\hline & & Xestospongia bocatorensis Díaz, Thacker, Rützler \& Piantoni, 2007 \\
\hline & & Neopetrosia rosariensis (Zea \& Rützler, 1983) \\
\hline & & Neopetrosia proxima (Duchassaing \& Michelotti, 1864) \\
\hline & & Neopetrosia subtriangularis (Duchassaing, 1850) \\
\hline & & Neopetrosia carbonaria (Lamarck, 1814) \\
\hline & & Petrosia sp. \\
\hline & & Petrosia (Petrosia) pellasarca (de Laubenfels, 1934) \\
\hline & & Petrosia weinbergi van Soest, 1980 \\
\hline & Phloeodictyidae & Oceanapia peltata (Schmidt, 1870) \\
\hline & & Oceanapia nodosa (George \& Wilson, 1919) \\
\hline & & Oceanapia oleracea (Schmidt, 1870) \\
\hline & & Oceanapia bartschi (de Laubenfels, 1934) \\
\hline & & Aka coralliphaga (Rützler, 1971) \\
\hline & & Siphonodictyon brevitubulatum Pang, 1973 \\
\hline & & Calyx podatypa (de Laubenfels, 1934) \\
\hline & Chalinidae & Chalinula molitba (de Laubenfels, 1949) \\
\hline & & Chalinula zeae de Weerdt, 2000 \\
\hline & & Haliclona sp. \\
\hline & & Haliclona (Rhizoniera) curacaoensis (van Soest, 1980) \\
\hline & & Haliclona (Reniera) implexiformis (Hechtel, 1965) \\
\hline & & Haliclona (Reniera) manglaris Alcolado, 1984 \\
\hline & & Haliclona (Reniera) mucifibrosa de Weerdt et al., 1991 \\
\hline & & Haliclona (Reniera) tubifera (George \& Wilson, 1919) \\
\hline & & Haliclona (Haliclona) vansoesti de Weerdt, de Kluijver \& Gomez, 1999 \\
\hline & & Haliclona (Haliclona) hogarthi (Hechtel, 1965) \\
\hline & & Haliclona (Halichoclona) albifragilis (Hechtel, 1965) \\
\hline
\end{tabular}


Table 1 continued

\begin{tabular}{|c|c|c|}
\hline Order & Family & Species \\
\hline & & Haliclona (Soestella) twincayensis de Weerdt et al., 1991 \\
\hline & & Haliclona (S.) vermeuleni de Weerdt, 2000 \\
\hline & & Haliclona (S.) caerulea (Hechtel, 1965) \\
\hline & & Haliclona (S.) piscaderaensis van Soest, 1980 \\
\hline & & Haliclona (Soestella) walentinae Díaz, Thacker, Rützler \& Piantoni, 2007 \\
\hline & & Haliclona (Halichoclona) magnifica de Weerdt, Rützler \& Smith, 1991 \\
\hline & & Haliclona (Gellius) megasclera Lehnert \& van Soest, 1996 \\
\hline & & Haliclona (Soestella) melana Muricy \& Ribeiro, 1999 \\
\hline & Niphatidae & Amphimedon compressa Duchassaing \& Michelotti, 1864 \\
\hline & & Amphimedon virdis Duchassaing \& Michelotti, 1864 \\
\hline & & Amphimedon erina (de Laubenfels, 1936) \\
\hline & & Amphimedon complanata (Duchassaing, 1850) \\
\hline & & Niphates sp. \\
\hline & & Niphates caycedoi (Zea \& van Soest, 1986) \\
\hline & & Niphates erecta Duchassaing \& Michelotti, 1864 \\
\hline & & Niphates amorpha Wiedenmayer, 1977 \\
\hline & & Cribrochalina vascum (Lamarck, 1814) \\
\hline & & Niphates ramosa Gammill, 1997 \\
\hline & Callyspongiidae & Callyspongia vaginalis (Duchassaing \& Michelotti, 1864) \\
\hline & & Callyspongia armigera Duchassaing \& Michelotti, 1864 \\
\hline & & Callyspongia fallax Duchassaing \& Michelotti, 1864 \\
\hline & & Callyspongia pallida (Hechtel, 1965) \\
\hline \multirow[t]{5}{*}{ Suberitida } & Suberitidae & Terpios sp. \\
\hline & & Terpios manglaris Rützler \& Smith, 1993 \\
\hline & & Prosuberites sp. \\
\hline & & Prosuberites laughlini Díaz et al., 1987 \\
\hline & & Suberites aurantiacus (Duchassaing \& Michelotti, 1864) \\
\hline \multirow[t]{15}{*}{ Clionaida } & Spirastrelliadae & Spirastrella sp. \\
\hline & & Spirastrella coccinea Schmidt, 1868 \\
\hline & & Spirastrella hartmani Boury-Esnault, Klautau, Bézac, Wulff \& Solé-Cava, 1999 \\
\hline & & Spirastrella cf. mollis Verill, 1907 \\
\hline & & Dipastrella megastelata Hechtel, 1965 \\
\hline & Placospongiidae & Placospongia intermedia/melobdeoides Sollas, 1888 \\
\hline & Clionaidae & Cliona sp. \\
\hline & & Cliona delitrix Pang, 1973 \\
\hline & & Cliona varians (Duchassaing \& Michelotti, 1864) \\
\hline & & Cliona caribbaea Carter, 1882 \\
\hline & & Cliona tenuis Carter, 1882 \\
\hline & & Cliona aprica Pang, 1973 \\
\hline & & Cliona mucronata Sollas, 1878 \\
\hline & & Spheciospongia vesparium (Lamarck, 1815) \\
\hline & & Cervicornia cuspidifera (Lamarck, 1815) \\
\hline \multirow[t]{6}{*}{ Tethyida } & Tethyidae & Tethya sp.1 \\
\hline & & Tethya sp.2 \\
\hline & & Tethya aff. seychellensis (Wright, 1881) \\
\hline & & Tethya actinea de Laubenfels, 1950 \\
\hline & & Tectitethya crypta (de Laubenfels, 1949) \\
\hline & & Tectitethya keyensis Sara \& Bavestrello, 1996 \\
\hline Polymastida & Polymastiidae & Polymastia sp. \\
\hline Poecilosclerida & Crambeidae & Monanchora arbuscula (Duchassaing \& Michelotti, 1864) \\
\hline
\end{tabular}


Table 1 continued

\begin{tabular}{|c|c|c|}
\hline Order & Family & Species \\
\hline & & Monanchora unguifera (Dendy, 1922) \\
\hline & Microcionidae & Clathria sp. \\
\hline & & Clathria (Thalysias) venosa (Alcolado, 1984) \\
\hline & & Clathria (Thalysias) microchela (Stephens, 1916) \\
\hline & & Clathria (Thalysias) schoenus (de Laubenfels, 1936) \\
\hline & & Clathria (Thalysias) echinata (Alcolado, 1984) \\
\hline & & Clathria ferrea (de Laubenfels, 1936) \\
\hline & & Clathria aspera Gammill, 1998 \\
\hline & & Artemisina melana van Soest, 1984 \\
\hline & & Holopsama helwigi (de Laubenfels, 1936) \\
\hline & & Pandaros acanthifolium Duchassaing \& Michelotti, 1864 \\
\hline & Acarnidae & Acarnus nicoleae van Soest, Hooper \& Hiemstra, 1991 \\
\hline & & Acarnus souriei (Lévi, 1952) \\
\hline & Mycalidae & Mycale sp. \\
\hline & & Mycale (Paresperella) sp. nov. \\
\hline & & Mycale (Mycale) laevis (Carter, 1882) \\
\hline & & Mycale (Arenochalina) laxissima (Duchassaing \& Michelotti, 1864) \\
\hline & & Mycale (Carmia) microsigmatosa Arndt, 1927 \\
\hline & & Mycale magnidarapihidiphera van Soest, 1984 \\
\hline & & Mycale carmigropila Hajdu \& Rützler, 1998 \\
\hline & & Mycale citrina Hajdu \& Rützler, 1998 \\
\hline & & Mycale arndti van Soest, 1984 \\
\hline & & Mycale cf. americana van Soest, 1984 \\
\hline & & Mycale angulosa (Duchassaing \& Michelotti, 1864) \\
\hline & & Mycale (Mycale) arenaria Hajdu \& Desqueyroux-Faúndez, 1994 \\
\hline & & Mycale cf. diversisigmata (van Soest, 1984) \\
\hline & Coelosphaeridae & Lyssodendoryx sp. \\
\hline & & Lissodendoryx issodictyalis (Carter, 1882) \\
\hline & & Lissodendoryx (Lissodendoryx) colombiensis Zea \& van Soest, 1986 \\
\hline & & Forcepia (Forcepia) colonensis Carter, 1874 \\
\hline & Tedaniidae & Tedania (Tedania) ignis (Duchassaing \& Michelotti, 1864) \\
\hline & & Tedania klausi Wulff, 2006 \\
\hline & Desmacididae & Desmapsamma anchorata (Carter, 1882) \\
\hline & lotrochotidae & lotrochota sp. \\
\hline & & lotrochota birotulata (Higgin, 1877) \\
\hline Merliida & Merliidae & Merlia normani Kirkpatrick, 1908 \\
\hline \multirow[t]{4}{*}{ Desmacellida } & Desmacellidae & Biemna sp. \\
\hline & & Biemna caribea Pulitzer-Finali, 1986 \\
\hline & & Biemna tubulata (Dendy, 1905) \\
\hline & & Neofibularia nolitangere (Duchassaing \& Michelotti, 1864) \\
\hline \multirow[t]{7}{*}{ Chondrillida } & Chondrillidae & Chondrilla caribensis f. hermatypica Duran \& Piantoni, 2007 \\
\hline & & Chondrilla caribensis f. caribensis Rützler, Duran \& Piantoni, 2007 \\
\hline & & Chondrosia sp. \\
\hline & & Chondrosia collectrix Schmidt, 1862 \\
\hline & & Chondrosia reniformis Nardo, 1847 \\
\hline & Halisacridae & Halisacra sp. \\
\hline & & Halisacra caerulea Vacelet \& Donadey, 1987 \\
\hline \multirow[t]{3}{*}{ Axinellida } & Raspaillidae & Ectyoplasia ferox (Duchassaing \& Michelotti, 1864) \\
\hline & Axinelliade & Dragmacidon reticulatum (Ridley \& Dendy, 1886) \\
\hline & & Dragmacidon lunaecharta (Ridley \& Dendy, 1886) \\
\hline
\end{tabular}


Table 1 continued

\begin{tabular}{|c|c|c|}
\hline Order & Family & Species \\
\hline & & Ptilocaulis walpersi (Duchassaing \& Michelotti, 1864) \\
\hline & & Axinellidae sp. \\
\hline & & Axinella corrugata (George \& Wilson, 1919) \\
\hline & & Dragmaxia cf. undata Alvarez, van Soest \& Rützler, 1998 \\
\hline & Heteroxyidae & Myrmekioderma sp. \\
\hline & & Myrmekioderma rea (de Laubenfels, 1934) \\
\hline & & Myrmekioderma gyroderma (Alcolado, 1984) \\
\hline \multirow[t]{5}{*}{ Suberitida } & Halichondriidae & Halichondria sp. \\
\hline & & Halichondria lutea Alcolado, 1984 \\
\hline & & Halichondria magniconulosa Hechtel, 1965 \\
\hline & & Halichondria melanadocia (de Laubenfels, 1936) \\
\hline & & Hymeniacidon caerulea Pulitzer-Finali, 1986 \\
\hline \multirow[t]{2}{*}{ Bubarida } & Desmanthidae & Petromica ciocalyptoides van Soest \& Zea, 1986 \\
\hline & Dictyonellidae & Svenzea zeai (Alvarez, van Soest \& Rützler, 1998) \\
\hline Scopalinida & Scopalinidae & Scopalina ruetzleri (Wiedenmayer, 1977) \\
\hline \multirow[t]{4}{*}{ Agelasida } & Agelasidae & Agelas sp. \\
\hline & & Agelas dispar (Duchassaing \& Michelotti, 1864) \\
\hline & & Agelas clathrodes (Schmidt, 1870) \\
\hline & & Agelas conifera (Schmidt, 1870) \\
\hline \multirow[t]{21}{*}{ Tetractinellida } & Theonellidae & Discodermia dissoluta Schmidt, 1870 \\
\hline & Samidae & Cinachyra sp. \\
\hline & & Samus anonymus Gray, 1867 \\
\hline & Tetillidae & Cinachyrella alloclada (Uliczka, 1929) \\
\hline & & Cinachyrella apion (Uliczka, 1929) \\
\hline & & Cinachyrella kuekenthali (Uliczka, 1929) \\
\hline & Geodiidae & Geodia sp. \\
\hline & & Geodia papyracea Hechtel, 1965 \\
\hline & & Geodia giberosa Lamarck, 1815 \\
\hline & & Erylus formosus Sollas, 1886 \\
\hline & Ancorinidae & Stellettinopsis megastylifera (Wintermann-Kilian \& Kilian, 1984) \\
\hline & & Asteropus sp. \\
\hline & & Penares sp. \\
\hline & & Penares schulzei (Dendy, 1905) \\
\hline & & Stelletta sp.1 \\
\hline & & Stelletta sp.2 \\
\hline & & Stelletta fibrosa Schmidt, 1862 \\
\hline & & Stryphnus raratriaenus Cárdenas, Menegola, Rapp \& Díaz, 2009 \\
\hline & Thoosidae & Alectona wallichii (Carter, 1874) \\
\hline & Thrombidae & Thrombus kittonii Carter, 1874 \\
\hline & Pachastrellidae & Triptolemma endolithicum van Soest, 2009 \\
\hline \multirow[t]{4}{*}{ Dendroceratida } & Darwinellidae & Aplysilla gracilis (Merejkowsky, 1878) \\
\hline & & Chellonaplysilla erecta (Row, 1911) \\
\hline & Dictyodendrillidae & Igernella notabilis (Duchassaing \& Michelotti, 1864) \\
\hline & & Spongionella (Megalopastas) sp. \\
\hline \multirow[t]{5}{*}{ Homosclerophorida } & Plakinidae & Plakortis angulospiculatus (Carter, 1879) \\
\hline & & Plakortis halichondrioides (Wilson, 1902) \\
\hline & & Plakortis simplex species complex Lehnert \& van Soest, 1998 \\
\hline & & Plakinastrella onkodes Uliczka, 1929 \\
\hline & & Oscarella sp. \\
\hline
\end{tabular}

After Guzmán and Guevara [21, 22], Collin et al. [13], Díaz [15], Díaz et al. [17], Gochfeld et al. [19] and Cárdenas et al. [10]; http://biogeodb.stri.si.edu/bocas_database/ search/class $/ 1 /$ ?page $=2$; compiled; with sponge species described in this study in bold 


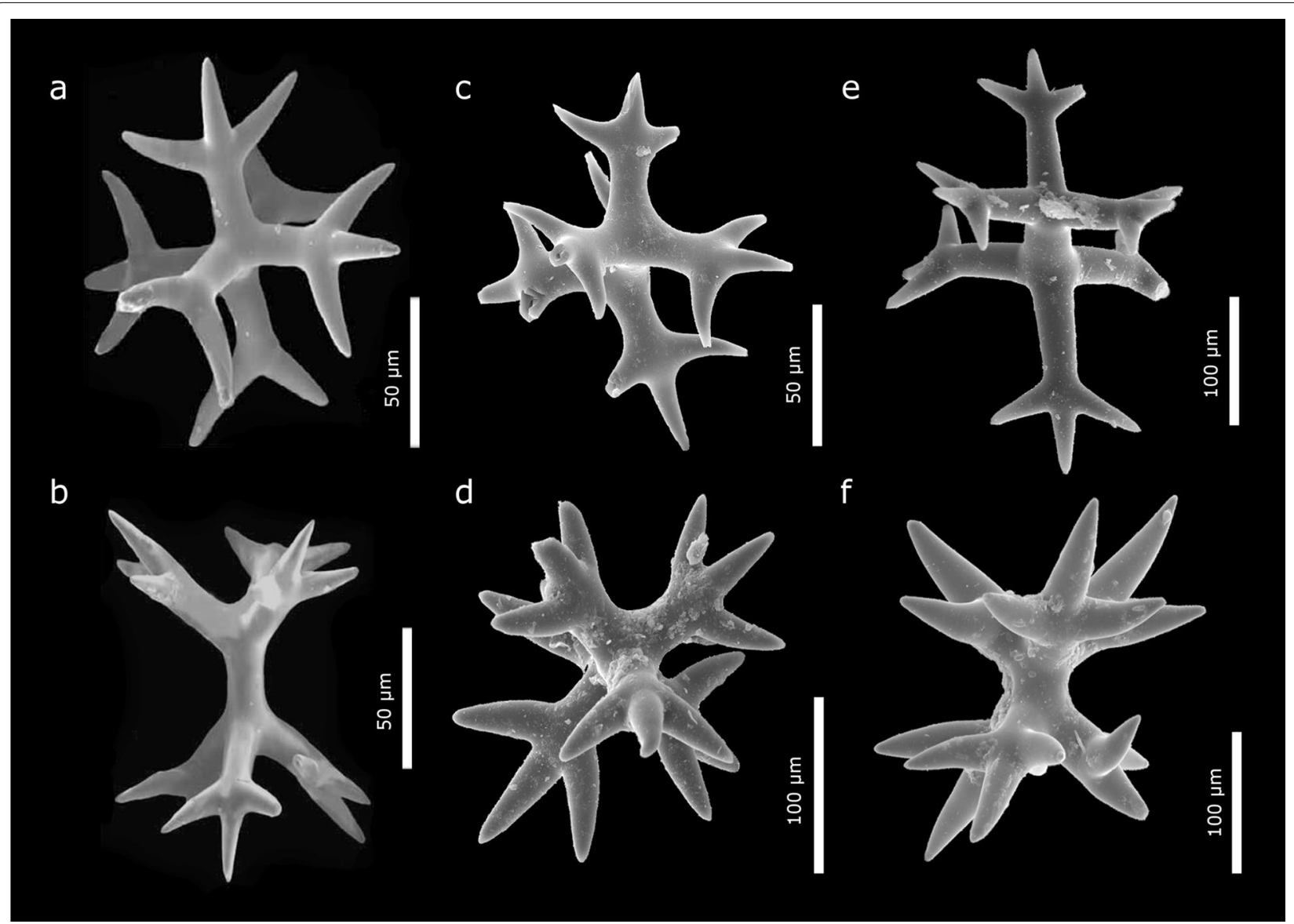

Fig. 2 Samus anonymus Gray, [20] spicules; a, b amphitriaenes of S. anonymus; from van Soest and Hooper [65], c-f sediment spicules

The thickness of the spicule exceeds $50 \mu \mathrm{m}$ in the thickest place and $30 \mu \mathrm{m}$ in the thinnest place, and the knobs are about $12 \mu \mathrm{m}$ in diameter. The tuberculate diactines of Alectona wallichii are very characteristic and do not resemble spicules of any other sponge, including thoosid species inhabiting this and adjacent areas (e.g., Alectona jamaicensis; [43]). In fact, the only other species of Alectona possessing morphologically similar acanthoxeas (but only those with spine-like tubercles, not the mushroom-like ones) is A. millari [12]. Alectona wallichii was synonymized by De Laubenfels [14] with Alectona millari [11]. However, Bavestrello et al. [3] demonstrated that these two species are distinct [48].

\section{Remarks}

The spicules of $A$. wallichii include robust tuberculate and smooth diactines (or derived polyactines) and microsclere amphiasters. The tuberculate diactines are acerate ([48]; Fig. 4a, b). These fusiform, slightly curved spicules are covered by rows ([11] describes twelve rows) of tubercles. The tubercles are alternately situated along the longitudinal lines placed along the spicule [11]. The tubercles may be of spine to mushroom shape [48]. The sizes of diactines vary from 22 to $805 \mu \mathrm{m} \times 16$ to $125 \mu \mathrm{m}$ (for more details, see Table 2 in $[48,57]$ ).

Alectona wallichii is an excavating thoosid that occupies chambers of coral skeletons [48] and molluscan shells [55].

Alectona wallichii is recorded from North Atlantic Ocean, Indian Ocean [55], Japan Sea, South Africa (Tulèar; WPD; [11], and Hawaii [57]).

\section{Short-shafted mesotriaenes of Triptolemma endolithicum van Soest, [64]}

The spicules described here extracted from the bottom sediments of the studied area are various types of mesodichotriaenes. Some of them possess short to moderately long, conically ended rhabds (Fig. 5c-e, g, h), and some others have blunt rhabds (Fig. $5 \mathrm{f}$ ). The cladomes may be branched only on the very end of the cladi, or the cladi may divide very near the rhabd. The clads are irregularly trifurcated or tetrafurcated (Fig. $5 \mathrm{~d}-\mathrm{g}$ ), with desmoid appearance in several different planes. The length of the rhabd varies from 40 to $65 \mu \mathrm{m}$. The cladomes are up to 


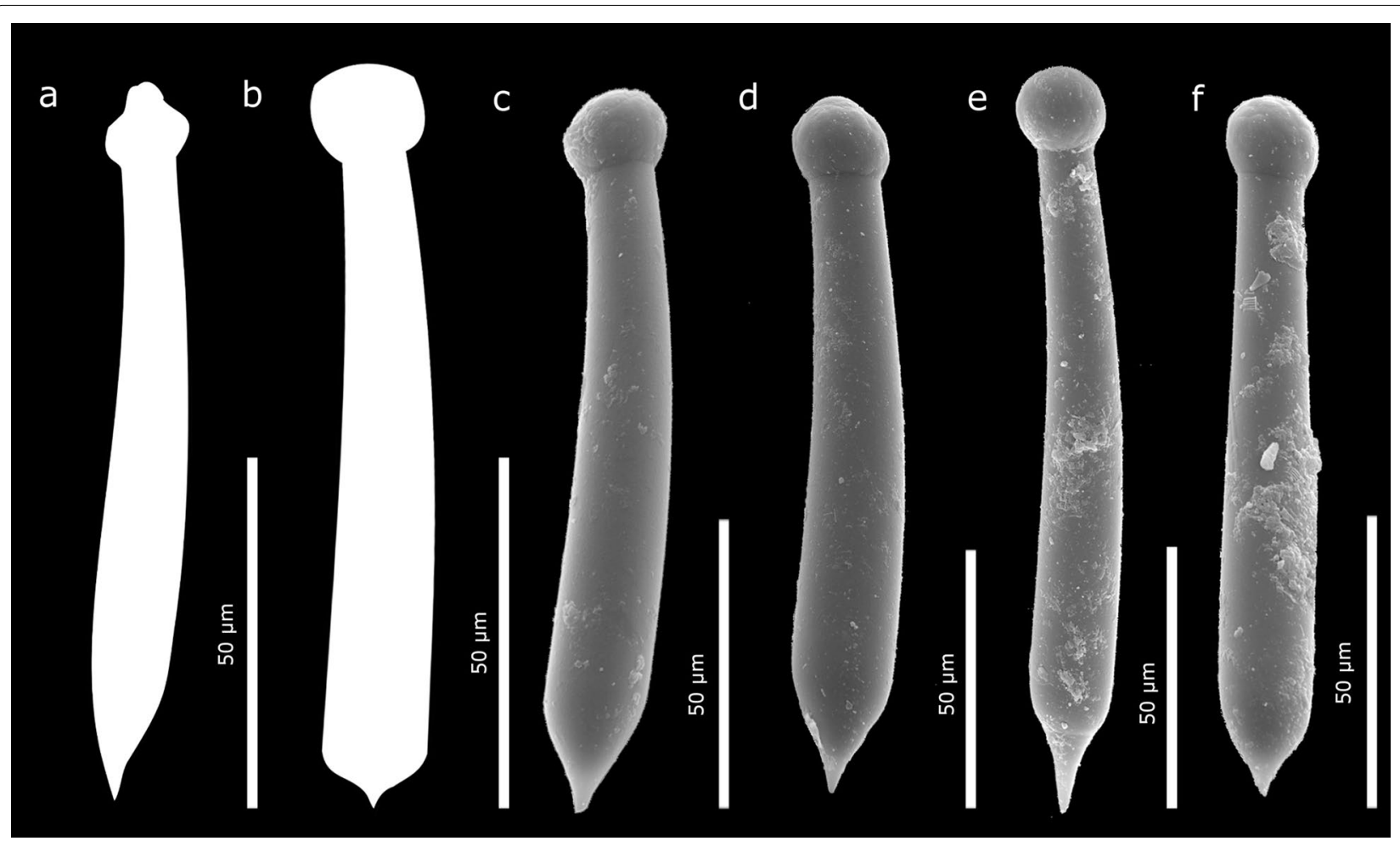

Fig. 3 Cliona mucronata Sollas, [52] spicules; a C. mucronata subtylostyle; redrawn from Vacelet and Vasseur [58], b C. mucronata subtylostyle; redrawn from Calcinai et al. [9], c-f sediment spicules

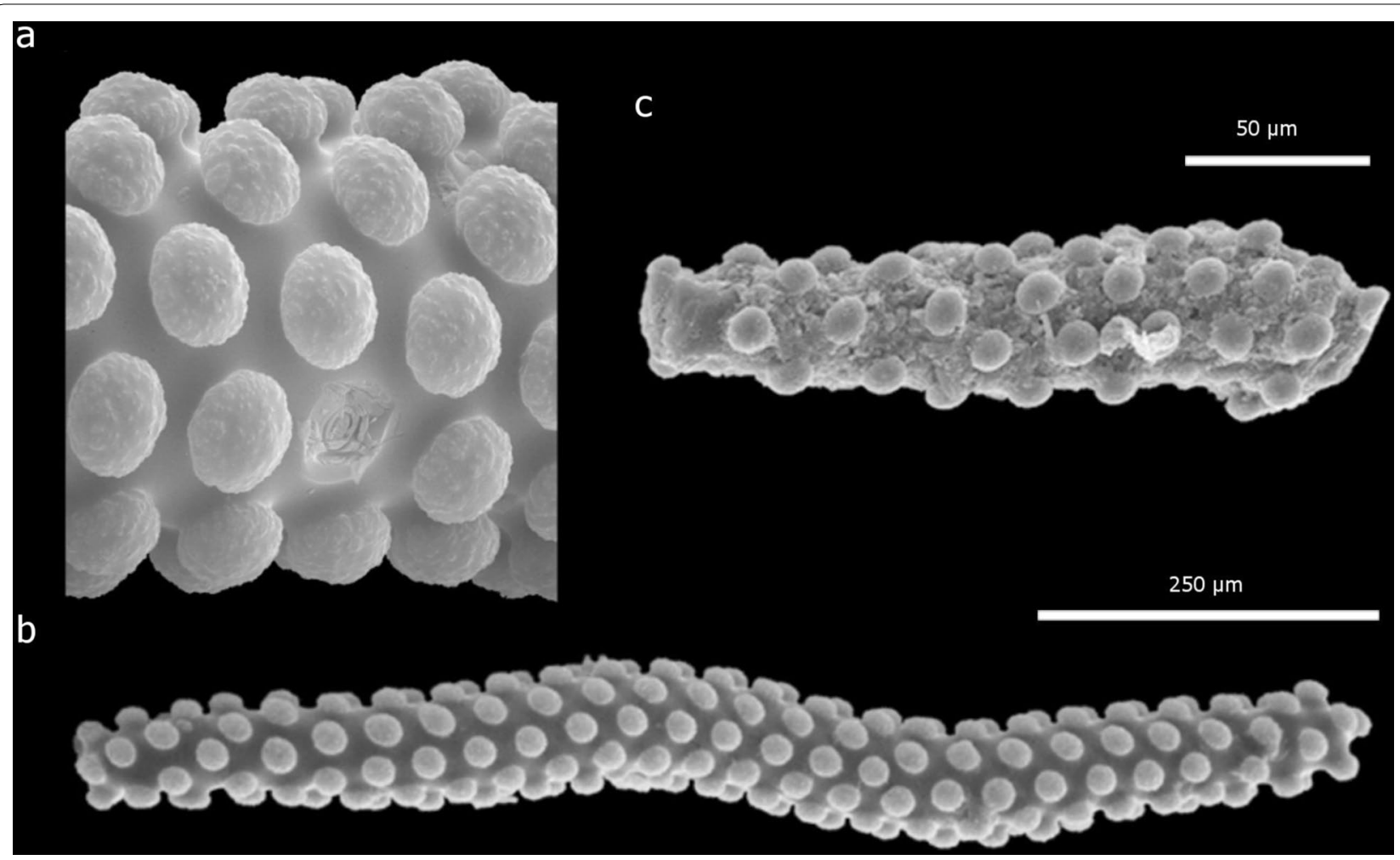

Fig. 4 Alectona wallichii [11] spicules; a mucronate diactine — fragment [57], b mucronate diactine; from Vacelet [57], c sediment spicule (fragment) 


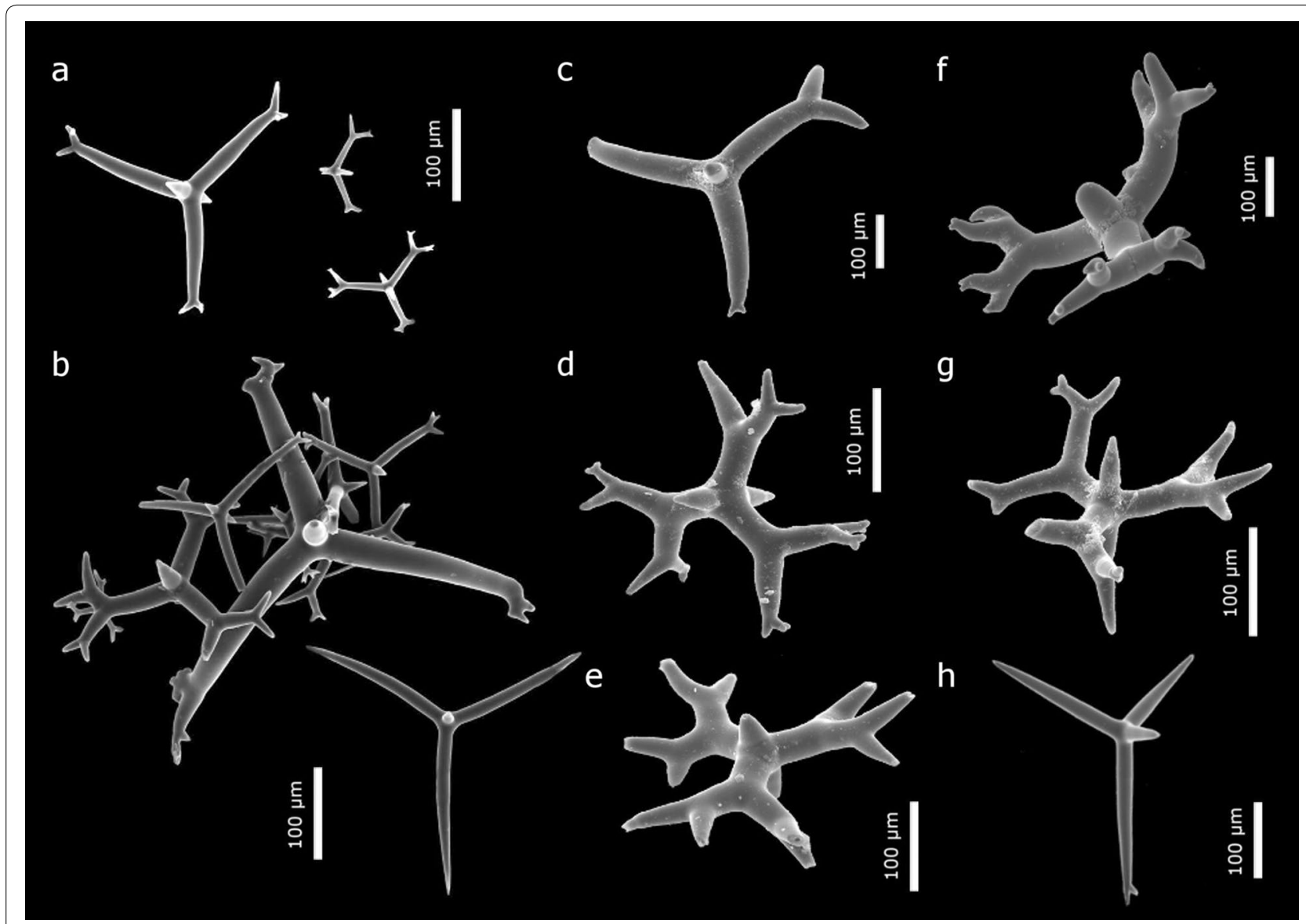

Fig. 5 Triptolemma endolithicum van Soest, [64] spicules; $\mathbf{a}, \mathbf{b}$ triaene and mesodichotriaenes of T. endolithicum; from van Soest [64], c-h sediment spicules

$300 \mu \mathrm{m}$. The protoclads are $30-180 \mu \mathrm{m}$, deuteroclads are 25-100 $\mu \mathrm{m}$ long, trichoclads are 20-55 $\mu \mathrm{m}$ long, and tetraclads are up to $10 \mu \mathrm{m}$ long. The mesodichotriaene megascleres of T. endholithicum resemble those of T. cladosum [53], but T. cladosum is known only in Indonesia [53].

\section{Remarks}

The skeleton of Triptolemma consists of short-shafted mesotriaenes (predominantly mesodichotriaenes) (Fig. 5a, b), frequently complemented by monaxonic megascleres (oxeas or strongyles), amphiasters, metasters transitional to spirasters, and spiny microrhabds which may be partially absent [4]. The mesotriaenes have symmetrical, short conical rhabdomes that can be blunt [38] or sharp pointed [64]. The clads may be irregularly trifurcated or tetrafurcated, with desmoid appearance. The cladome branches out in several different planes. Also the level of division varies within a spicule with dichotomous and tetrafurcated clads co-occurring [38]. Mesotriaenes with diversely branched clads may differ according to size within one specimen [64]. The rhabdomes are $62-21 \times 20-25 \mu \mathrm{m}$ each. The cladomes are up to $400 \mu \mathrm{m}$ [64] and include protoclads 21-302 × 12-48 $\mu \mathrm{m}$, deuteroclads $12-72 \times 6-20 \mu \mathrm{m}$, trichoclads $6-60 \times 5-7 \mu \mathrm{m}$, and tetraclads up to $27.6 \mu \mathrm{m}$ long.

Sponges of the genus Triptolemma are cryptic and penetrate other sponges or coral tissue [38], or crevices of the coralligenous concretions [4]. Triptolemma endolithicum is an encrusting species, growing on and in corals. It is usually not visible on the outer surface of the coral, but there are some cavities and corridors filled with Triptolemma in the coral inner part [64].

Triptolemma endolithicum was so far noted only in the Southern Caribbean (i.e., Colombia) by van Soest [64].

\section{Discussion}

The surficial sediment deposited in the areas inhabited by sponges is usually loaded with their spicules. Usually, when the sponge skeleton becomes incorporated into the sediment, it disintegrates rapidly to isolated spicules. However, under favorable conditions, the spicules 
may stay connected together with the collagenous fibrils forming small skeletal clusters. Nevertheless, the latter situation is rather rare and after some time, due to early diagenesis and bioturbation, the spicules become separated, broken, and sometimes selectively segregated (for more details see $[36,50])$.

The spicules may be delivered to the bottom sediments in various ways. Some could have belonged to sponge specimens that were mechanically damaged (e.g., during the storms) but not killed. The pieces of the torn sponge tissue settle on the sea bottom and then become incorporated to the sediment either as clusters of sponge spicules or as loose spicules. Also, sponge-eating carnivores, such as some opisthobranches, sea stars, fishes, and turtles, can deliver sponge spicules to the sediment. As the predators consume only small parts rather than whole individuals [72], the sponges may remain alive as well, and only their fragments are detached. In both cases mentioned above, the sponge species might still be present in this area.

By contrast, when a sponge dies, its spicule complement becomes incorporated to the sediment. The spicules are thus the proof of the former presence of the sponge individual and do not necessarily indicate that the species occurs in that area.

It was already suggested that some spicule morphotypes have a greater chance of being preserved in the sediment than others (see [50]), e.g., those of spherical morphology (e.g., spherasters and selenasters) are quite resistant to mechanical destruction. Thus, they might be a dominant component of sponge spicule assemblages (for more details, see $[36,50]$ ) only for taphonomic reasons.

The additional factor is spicule transport. The sediment containing spicules might be carried from other, more or less distant areas e.g., by currents or hurricanes [40].

Finally, the activity of bioturbating organisms has to be considered. Organisms responsible for bioturbation are mostly oligochaetes, polychaetes, bivalves, echinoids, and holothurians [34, 41]. The disturbance and homogenization of the deposits can reach down to about 3-4 cm [34], but in extreme cases, it can exceed even $20-40 \mathrm{~cm}$ $[47,60]$. Such activity causes reworking and mixing of the sediment that could have been deposited during the last few weeks to tens of years (depending on sedimentation rate).

One has to be aware that spicules in the sediment are a mixture possibly resulting from these processes. Thus, finding spicules that belong to certain sponge species in the surficial sediment is a proof of one or more of the three following processes: (1) the presence of living individuals bearing this type of spicule in this, or nearby areas, (2) the former presence of the sponge bearing this spicule type, or (3) the transport of this spicule morphotype from other (more or less distant) areas.

In the case of the studied sponge spicules, the transport seems not to have played a significant role as most of the species recognized on the basis of the spicules are characteristic for this environment being shallow-water inhabitants. Moreover, this area is not influenced by hurricanes (Aaron O'Dea personal communication). The transport from deeper water is less likely, too. Moreover, some of these spicule morphotypes were quite numerous in the studied sediment (amphitriaenes) which also suggests the autochthonous character of the studied spicule assemblage. Their absence from the sponge list from this area is caused probably by the fact that all of them are cryptic or excavating. It is thus highly plausible that they represent species that still live in the investigated area, but were just overlooked.

\section{Conclusions}

The spicular analysis method may be used as an additional tool for tracing sponge species in marine and fresh-water environments all over the world.

Nevertheless, usage of this method is burdened by some limitations:

1. The method only suggests, does not prove, the presence of species in the studied area (conventional taxonomic studies are necessary to confirm the presence of the species).

2. It is suitable only for tracking sponges with very characteristic, highly diagnostic spicule types.

3. It is best applied in areas with no significant sediment transport and mixing.

In Bocas del Toro lagoon, the method of spicular analysis has suggested the presence of four cryptic and/or excavating sponge species unknown in this area before. Those were Samus anonymus, Alectona wallichii, Triptolemma endolithicum, and Cliona mucronata.

\section{Acknowledgements}

This study was financed by a research Grant from the National Science Centre (NCN) Poland No. 2013/09/D/ST10/04050. The studies made in 2011 were supported by Short Term Fellowship from the Smithsonian Tropical Research Institute and PalSIRP Sepkoski Grant. This paper was also possible thanks to support of the Institute of Paleobiology, Polish Academy of Sciences. I would like to thank all the people who helped me with collecting and processing the material: M. Hynes (STRI Research Intern), B. de Gracia (STRI), and A. O'Dea (STRI). D. Madzia (Institute of Paleobiology), M. Hynes (STRI Research Intern), and A. Jagtap (Northeastern University) are thanked for linguistic improvements of the manuscript. I would like to thank G. Jacome, P. Gondola, F. Rodriguez, and all the team at the Bocas Research Station for their support. Special thanks are to J. Vacelet (Aix-Marseille Université) for providing me photographs of A. wallichii and A. Pisera (Institute of Paleobiology) for critical reading of the manuscript and discussion. I am also indebted to the reviewers which suggestions helped to considerably improve this manuscript. 


\section{Competing interests}

The authors declare that they have no competing interests.

Received: 19 October 2015 Accepted: 16 January 2016 Published online: 20 April 2016

\section{References}

1. Alcolado PM. Nuevas especies de esponjas encontradas en Cuba [new species of sponges from Cuba]. Poeyana. 1984;271:1-22.

2. Bautista-Guerrero E, Carballo JL, Cruz-Barraza JA, Nava HH. New coral reef boring sponges (Hadromerida: Clionaidae) from the Mexican Pacific Ocean. J Mar Biol Assoc UK. 2006;86(5):963-70.

3. Bavestrello G, Calcinai B, Cerrano C, Sara M. Alectona species from North-Western Pacific (Demospongiae: Clionidae). J Mar Biol Assoc UK. 1998;78:59-73.

4. Bertolino M, Pica D, Bavestrello G, Iwasaki N, Calcinai B. A new species of Triptolemma (Porifera, Pachastrellidae) from the Pacific Ocean with a revision of the genus. J Mar Biol Assoc UK. 2011;91(2):329-38.

5. Bertolino M, Calcinai B, Cappellacci S, Cerrano C, Lafratta A, Pansini M, Penna A, Bavestrello G. Posidonia oceanica meadows as sponge spicule traps. Ital J Zool. 2012;79(2):231-8. doi:10.1080/11250003.2011.614641.

6. Bertolino M, Cerrano C, Bavestrello G, Carella M, Pansini M, Calcinai B. Diversity of Porifera in the Mediterranean coralligenous accretions, with description of a new species. Zookeys. 2013:336:1-37.

7. Bertolino M, Calcinai B, Cattaneo-Vietti R, Cerrano C, Lafratta A, et al. Stability of the sponge assemblage of the Mediterranean coralligenous along a millennial span of time. Mar Ecol. 2014;35:149-59. doi:10.1111/ maec.12063.

8. Boury-Esnault N, Rützler K, editors. Thesaurus of sponge morphology. Smithsonian contributions to zoology, vol. 596. Washington: Smithsonian Institution Press; 1997. p. 55.

9. Calcinai B, Bavestrello G, Cerrano C. Excavating sponge species from the Indo-Pacific Ocean. Zool Stud. 2005;44:5-18

10. Cárdenas P, Menegola C, Rapp HT, Díaz MC. Morphological description and DNA barcodes of shallow-water Tetractinellida (Porifera: Demospongiae) from Bocas del Toro, Panama, with description of a new species. Zootaxa. 2009;2(2276):1-39.

11. Carter HJ. Descriptions and figures of deep-sea sponges and their spicules from the Atlantic Ocean, dredged up on board H.M.S. 'Porcupine', chiefly in 1869; with figures and descriptions of some remarkable Spicules from the Agulhas Shoal and Colon, Panama. Ann Mag Nat Hist. 1874;14(207-221):245-57.

12. Carter HJ. On a new species of excavating sponge (Alectona millari); and on a new species of Rhaphidotheca (R. affinis). J Roy Microsc Soc. 1879:2:493-9.

13. Collin R, Díaz M, Norenburg J, Rocha R, Sanchez J, Schulz A, Schwartz M, Valdes A. Photographic identification quide to some common marine invertebrates of Bocas Del Toro, Panama. Caribb J Sci. 2005;41:638-707.

14. De Laubenfels MW. A discussion of the sponge fauna of the Dry Tortugas in particular and the West Indies in general, with material for a revision of the families and orders of the Porifera. Carnegie Institute of Washington (Tortugas laboratory paper no 467), vol. 30; (1936), pp. 1-225.

15. Díaz MC. Common sponges from shallow marine habitats from Bocas del Toro region, Panama. Caribb J Sci. 2005;41:465-75.

16. Díaz MC, Rützler K. Sponges: an essential component of Caribbean coral reefs. Bull Mar Sci. 2001:69(2):535-46.

17. Díaz MC, Thacker RW, Rützler K, Piantoni C. Two new haplosclerid sponges from Caribbean Panama with symbiotic filamentous cyanobacteria, and an overview of sponge cyanobacteria associations. In: Custódio MR, Lôbo-Hajdu G, Hajdu E, Muricy G, editors. Porifera research: biodiversity, innovation and sustainability. Série Livros 28, vol. 28. Rio de Janeiro: Museu Nacional; 2007. p. 31-9.

18. Fromont J, Abdo DA. New species of Haliclona (Demospongiae: Haplosclerida: Chalinidae) from Western Australia. Zootaxa. 2014;3835:97-109.

19. Gochfeld D, Schlöder C, Thacker RW. Sponge community structure and disease prevalence on coral reefs in Bocas del Toro, Panama. In: Custódio MR, Lôbo-Hajdu G, Hajdu E, Muricy G, editors. Porifera research: biodiversity, innovation, and sustainability. Série Livros 28. Rio de Janeiro: Museu Nacional; 2007. p. 335-43
20. Gray JE. Notes on the arrangement of sponges, with the descriptions of some New Genera. Proc Zool Soc Lond. 1867;1867(2):492-558.

21. Guzmán HM, Guevara CA. Arrecifes coralinos de Bocas del Toro, Panamá: II. Distribución, estructura, y estado de conservación de los arrecifes de las islas de Bastimentos, Solarte. Carenero y Colon Rev Biol Trop. 1998;46:889-912.

22. Guzmán HM, Guevara CA. Arrecifes coralinos de Bocas del Toro, Panamá: III. Distribución, estructura, y estado de conservación de los arrecifes de las islas Pastores, Cristobal, Popa, y Cayo Agua. Rev Biol Trop. 1999;47:659-76

23. Hajdu E, Rützler K. Sponges, genus Mycale (Poecilosclerida: Demospongiae: Porifera), from a Caribbean mangrove and comments on subgeneric classification. Proc Biol Soc Wash. 1998;111(4):737-73.

24. Hall KV, Herrmann SJ. Paleolimnology of three species of freshwater sponges (Porífera: Spongilidae) from a sediment core of a Colorado semidrainage mountain lake. Trans Am Microsc Soc. 1980;99:93-100.

25. Harrison FW. Utilization of freshwater sponges in paleolimnological studies. Palaeogeogr Palaeoecol. 1988;62:387-97.

26. Harrison FW, Gleason PJ, Stone PA. Paleolimnology of lake Okeechobee, Florida: an analysis utilizing spicular components of freshwater sponges (Porifera: Spongillidae). Not Nat. 1979:454:1-6.

27. Heyward A, Fromont J, Schönberg CHL, Colquhoun J, Radford B, Gomez O. The sponge gardens of Ningaloo Reef, Western Australia. Op Mar Biol J. 2010;4:3-11.

28. Hogg MM, Tendal OS, Conway KW, Pomponi SA, van Soest RWM, Gutt J, Krautter M, Roberts JM. Deep-sea sponge grounds: reservoirs of biodiversity. UNEP-WCMC biodiversity series no. 32. Cambridge: UNEP-WCMC 2010

29. Hooper JNA, van Soest RWM, editors. Systema Porifera: a guide to the classification of sponges. New York: Kluwer; 2002. p. 1-1101.

30. Inoue M. Correlation of the spicule assemblage in the sediment with the spicule assemblage of living sponges in Sagami Bay, Central Japan. Proc Jap Acad. 1984;60B:165-8.

31. Inoue M. An examination of supply processes of sponge spicules to the sediment of the Northeastern to Eastern part of Sagami Bay. In: Annual report of the faculty of education, Iwate University, vol. 44; 1985, pp $61-80$

32. Koltun VM. Siliceous horny sponges of the northern and fareastern seas of the USSR. Zool Muz Akad Nauk. 1959:67:1-236 [In Russian].

33. Koltun VM. Spicules of siliceous sponges in Upper Cretaceous and Paleogene sediments of the northern Ural. Paleontol J. 1961;1:61 [in

\section{Russian}

34. Kristensen E, Penha-Lopes G, Delefosse M, Valdemarsen T, Quintana CO, Banta GT. What is bioturbation? The need for a precise definition for fauna in aquatic sciences. Mar Ecol Prog Ser. 2012;446:285-302. doi:10.3354/ meps09506.

35. Leys SP, Mackie GO, Reiswig HM. The biology of glass sponges. Adv Mar Biol. 2007:52:1-145.

36. Łukowiak M, Pisera A, O'Dea A. Do spicules in sediments reflect the living sponge community? A test in a Caribbean shallow water lagoon. Palaios. 2013;28:373-85.

37. Łukowiak M, Pisera A, Schlögl J. Siliceous sponges from the bathyal deposits of the Late Early Miocene Vienna Basin (Central Paratethys, Slovakia). Paläont Z. 2014;88:263-77.

38. Maldonado M. Family pachastrellidae. In: Hooper JNA, van Soest RWM, editors. Systema Porifera. A guide to the classification of sponges. New York: Kluwer; 2002. p. 141-62.

39. Maldonado M, Uriz MJ. Skeletal morphology of two controversial poecilosclerid genera (Porifera Demospongiae): Discorhabdella and Crambe. Helgoländer Meeresuntersuchungen. 1996;50:369-90.

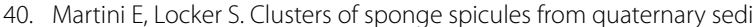
ments at sites 685 and 688 off Peru. Proc ODP Sci Res. 1990;112:185-90.

41. Mermillod-Blondin F. The functional significance of bioturbation and biodeposition on biogeochemical processes at the water-sediment interface in freshwater and marine ecosystems. J N Am Benthol Soc. 2011;30:770-8.

42. Morrow C, Cárdenas P. Proposal for a revised classification of the Demos pongiae (Porifera). Front Zool. 2015;12:7.

43. Pang RK. The systematics of some Jamaican excavating sponges (Porifera). Postilla. 1973:161:1-75. 
44. Parolin M, Volkmer-Ribeiro C, Stevaux JC. Sponge spicules in peaty sediments as paleoenvironmental indicators of the Holocene in the upper Paraná river, Brazil. Rev Bras Paleontol. 2007;10:17-26.

45. Parolin M, Volkmer-Ribeiro C, Stevaux JC. Use of spongofacies as a proxy for river-lake paleohydrology in quaternary deposits of Central-Western Brazil. Rev Bras Paleontol. 2008;11:187-98.

46. Pisera A, Cachao M, da Silva C. Siliceous sponge spicules from the Miocene Mem Moniz marls (Portugal) and their environmental significance. Riv Ital Paleontol. 2006;1 12:287-99.

47. Rüsgård HU, Banta GT. Irrigation and deposit feeding by the lugworm Arenicola marina, characteristics and secondary effects on the environment. A review of current knowledge. Vie Milieu. 1998;48:243-57.

48. Rützler K. Family Alectonidae Rosell, 1996. In: Hooper JNA, van Soest RWM, editors. Systema Porifera. A guide to the classification of sponges 1. New York: Kluwer; 2002. p. 281-90

49. Rützler. Family Clionaidae D'Orbigny, 1851. In: Hooper JNA, van Soest RWM, editors. Systema Porifera: a guide to the classification of sponges. New York: Kluwer; 2002. p. 173-85.

50. Rützler K, Macintyre I. Siliceous sponge spicules in coral reef sediments. Mar Biol. 1978:49:147-59.

51. Rützler K, Piantoni C, Soest van RMW, Díaz MC. Diversity of sponges (Porifera) from cryptic habitats on the Belize barrier reef near Carrie Bow Cay. Zootaxa. 2014;3805(1):1-129.

52. Sollas WJ. On two new and remarkable species of Cliona. Ann Mag Nat Hist. 1878;1:54-66.

53. Sollas WJ. Report on the Tetractinellida collected by H.M.S. Challenger, during the years 1873-1876. Report on the scientific results of the Voyage of H.M.S. Challenger, 1873-1876. Zoology. 1888;25:1-458.

54. Stone RP, Lehnert $\mathrm{H}$, Reiswig $\mathrm{H}$. A guide to the deepwater sponges of the Aleutian Island Archipelago. NOAA professional paper NMFS, vol. 12; 2011, 187p.

55. Sunil Kumar P, Thomas PA. Discovery of Alectona wallichii (Carter 1874) from the Indian seas as a pest of brown mussel with notes on the zoogeography and substratum preference in Alectona spp. (Demospongiae: Alectonidae). J Mar Biol Assoc Ind. 2012;54:80-4. doi:10.6024/ jmbai.2012.54.2.01718-13.

56. Topsent E. Spongiaires de I'Atlantique et de la Méditerranée provenant des croisières du Prince Albert ler de Monaco. Résultats des campagnes scientifiques accomplies par le Prince Albert I. Monaco. 1928;74:1-376.

57. Vacelet J. Planktonic armoured propagules of the excavating sponge Alectona (Porifera: Demospongiae) are larvae: evidence from Alectona wallichii and A. mesatlantica sp. nov. Mem Queens Mus. 1999;44:627-42.

58. Vacelet J, Vasseur P. Éponges des récifs coralliens de Tuléar (Madagascar) Téthys Suppl. 1971;1:51-126.

59. Vacelet J, Vasseur P, Lévi C. Spongiaires de la pente externe des récifs coralliens de Tuléar (Sud-Ouest de Madagascar). Mém Mus Nat Hist Nat (A, Zoologie). 1976;49:1-116

60. Valdemarsen T, Wendelboe K, Egelund JT, Kristensen E, Flindt MR. Exclusion of seagrass by benthic invertebrates; burial of eelgrass seeds and seedlings by the lugworm (Arenicola marina). J Exp Mar Biol Ecol. 2011:410:45-52
61. van Soest RWM. Marine sponges from Curaçao and other Caribbean localities. Part II. Haplosclerida. In: Hummelinck PW, Van der Steen LJ (eds) Uitgaven van de Natuurwetenschappelijke Studiekring voor Suriname en de Nederlandse Antillen No. 104. Stud F Curaçao Caribb Isl, vol 62; 1980, pp. 1-173.

62. van Soest RWM. Marine sponges from Curaçao and other Caribbean localities. Part III. Poecilosclerida. In: Hummelinck PW, Van der Steen LJ (eds) Uitgaven van de Natuurwetenschappelijke Studiekring voor Suriname en de Nederlandse Antillen No. 112. Stud F Curaçao Caribb Isl, vol. 62; 1984, pp. 1-173.

63. van Soest RWM. Demosponge distribution patterns. In: van Soest RWM Kempen TMG, van Braekman J-C, editors. Sponges in time and space. Rotterdam: Balkema; 1994. p. 213-24.

64. van Soest RWM. New sciophilous sponges from the Caribbean (Porifera: Demospongiae). Zootaxa. 2009;2107:1-40.

65. van Soest RWM, Hooper JNA. Family Samidae Sollas, 1886. In: Hooper JNA, van Soest RWM, editors. Systema Porifera: a guide to the classification of sponges 1. New York: Kluwer; 2002. p. 99-101.

66. van Soest RWM, Boury-Esnault N, Vacelet J, Dohrmann M, Erpenbeck D, et al. Global diversity of sponges (Porifera). PLoS One. 2012;7:e35105.

67. van Soest RWM, Meesters EHWG, Becking LE. Deep-water sponges (Porifera) from Bonaire and Klein Curaçao, Southern Caribbean. Zootaxa. 2014;3878:401-43.

68. van S, Boury-Esnault N, Hoope, JNA, Rützler K, de Voogd NJ, Alvarez de Glasby B, Hajdu E, Pisera AB, Manconi R, Schoenberg C, Janussen D, Tabachnick KR, Klautau M, Picton B, Kelly M, Vacelet J, Dohrmann M, Díaz M-C, Cárdenas P. World Porifera database. http://www.marinespecies.org/ porifera on 14 Nov 2014

69. Volkmer-Ribeiro C, Turcq B. SEM analysis of silicious spicules of a freshwater sponge indicate paleoenvironmental changes. Acta Microsc. 1996;5:186-7.

70. Volkmer-Ribeiro C, Ezcurra de Drago I, Parolin M. Spicules of the freshwater sponge Ephydatia facunda indicate lagoonal paleoenvironment at the Pampas of Buenos Aires Province, Argentina. J Coast Res. 2007;50:449-52.

71. Wiedenmayer F. Contribution of the knowledge of post-Paleozoic neritic and archibenthal sponges (Porifera). Schweiz Paläont Mitt. 1994;116:1-147.

72. Wulff JL. Ecological interactions of marine sponges. Can J Zool Spec Ser. 2006;84:146-66.

73. Zea S, van Soest RWM. Three new species of sponges from the Colombian Caribbean. B Mar Sci. 1986;3:355-65.

74. Zea S, Weil E. Taxonomy of the Caribbean excavating sponge species complex Cliona caribbaea - C. aprica - C. langae (Porifera, Hadromerida, Clionaidae). Caribb J Sci. 2003;39:348-70.

\section{Submit your next manuscript to BioMed Central and we will help you at every step:}

- We accept pre-submission inquiries

- Our selector tool helps you to find the most relevant journal

- We provide round the clock customer support

- Convenient online submission

- Thorough peer review

- Inclusion in PubMed and all major indexing services

- Maximum visibility for your research

Submit your manuscript at www.biomedcentral.com/submit
C Biomed Central 